\title{
Mix design, properties and cost analysis of fly ash-based geopolymer foam
}

\author{
Z. Abdollahnejad ${ }^{a}$, F. Pacheco-Torgal ${ }^{\mathrm{a}, *}$, T. Félix ${ }^{\mathrm{b}}$, W. Tahri ${ }^{\mathrm{c}}$, J. Barroso Aguiar $^{\mathrm{a}}$ \\ ${ }^{a}$ C-TAC, University of Minho, Portugal \\ ${ }^{\mathrm{b}}$ Civil Engineering Department, University of Minho, Portugal \\ ${ }^{\mathrm{C}}$ University of Sfax, Tunisia
}

\section{H I G H L I G H T S}

- Mix design of fly ash foam geopolymer.

- Mixtures with $0.1 \mathrm{~W} /(\mathrm{m} \mathrm{K})$ therm. conductivity and a 6 MPa comp. strength were achieved.

- Foaming agents cost represent less than $10 \%$ of foam geopolymer cost.

\section{A R T I C L E I N F O}

\section{Article history:}

Received 1 November 2014

Received in revised form 10 January 2015

Accepted 13 January 2015

\section{Keywords:}

Energy efficiency

Thermal insulators

Foam geopolymers

Mix design

Cost analysis

\begin{abstract}
A B S T R A C T
This study has investigated the joint effect of several mix parameters on the properties of foam geopolymers. The mix parameters analysed through a laboratory experiment of 54 different mortar mixes were, sodium silicate/sodium hydroxide mass ratio $(2.5,3.5,4.5)$, activator/binder mass ratio $(0.6,0.8,1.0)$, chemical foaming agent type (hydrogen peroxide $\left(\mathrm{H}_{2} \mathrm{O}_{2}\right)$ and sodium perborate $\left(\mathrm{NaBO}_{3}\right)$ ) and foaming agent mass ratio content (1\%,2\%,3\%). Properties, SEM and FTIR analysis and cost analysis are included. The results show that the sodium perborate over performs hydrogen peroxide leading to a lower overall thermal conductibility of foam geopolymers. Mixtures with a low thermal conductivity of around $0.1 \mathrm{~W} /$ $(\mathrm{m} \cdot \mathrm{K})$ and a compressive strength of around $6 \mathrm{MPa}$ were achieved. The cost analysis show that the foaming agents are responsible for a small percentage of foam geopolymers total cost being that the alkaline activators are responsible for more than $80 \%$.
\end{abstract}

(c) 2015 Elsevier Ltd. All rights reserved.

\section{Introduction}

The increasing demand for worldwide energy, is a major cause for the unsustainable development of our Planet. Between 2007 and 2030 energy demand have grown about 40\% reaching 16.8 billion tonnes of equivalent petroleum-TEP [1].The rise in energy consumption has two main reasons, the increase in world population and the fact that there are an increasing number of people with access to electricity. Currently, 1.5 billion people still have no access to electricity [2]. Besides since urban human population will almost double, increasing from approximately 3.4 billion in 2009 to 6.4 billion in 2050 [3] this will dramatically increase electricity demand. Beyond what energy consumption means in terms of using non-renewable fossil materials, the highest environmental impact of energy consumption, has to do with carbon dioxide emissions, generated during the burning of coal and gas for

\footnotetext{
* Corresponding author.

E-mail address: torgal@civil.uminho.pt (F. Pacheco-Torgal).
}

electricity generation in power stations. Given that buildings consume throughout their life cycle, more than $40 \%$ of all energy produced [4], we can easily see the high energy saving potential that this subsector may represent in terms of reducing carbon dioxide emissions. Energy efficiency is the most cost effective way to reduce emissions, improve competitiveness and create employment. The Energy Road Map 2050 [5] confirmed that higher energy efficiency in new and existing buildings is key for the transformation of the EU's energy system. COM 815 [6] mentions that the Union's energy efficiency target of saving 20\% of energy by 2020 could cut consumers' bills by up to $€ 1000$ per household a year and improving Europe's industrial competitiveness and creating up to 2 million new jobs by 2020.The European Energy Performance of Buildings Directive 2002/91/EC (EPBD) has been recast in the form of the 2010/31/EU by the European Parliament on 19 May 2010. One of the new aspects of the EPBD that reflects an ambitious agenda on the reduction of the energy consumption is the introduction of the concept of nearly zero-energy building [7]. The use of thermal insulation materials constitutes the most 
Table 1

Characteristics of the aggregates.

\begin{tabular}{lllll}
\hline & $\begin{array}{l}\text { Max dimension } \\
(\mathrm{mm})\end{array}$ & $\begin{array}{l}\text { Fine } \\
\text { content }\end{array}$ & $\begin{array}{l}\text { Density }(\mathrm{kg} / \\
\left.\mathrm{m}^{3}\right)\end{array}$ & $\begin{array}{l}\text { Water } \\
\text { absorption }\end{array}$ \\
\hline $\begin{array}{l}\text { Sand } \\
\text { Coarse }\end{array}$ & 4.0 & $\leqslant 3$ & 2660 & 0.2 \\
$\quad 8.0$ & $\leqslant 1.5$ & 2620 & 0.6 \\
\hline aggregates & & & & \\
\hline
\end{tabular}

effective way of reducing heat losses in buildings thus reducing heat energy needs. These materials are very important for the building material industry representing a 21 billion $€$ market share [8]. With the exception of expanded cork, which is based on a renewable and completely recyclable material, all the other current insulation materials are associated with negative impacts in terms of toxicity. Polystyrene, for example contains anti-oxidant additives and ignition retardants, additionally, its production involves the generation of benzene and chlorofluorocarbons. On the other hand, polyurethane is obtained from isocyanates, which are widely known for their tragic association with the Bhopal disaster. Besides, they release toxic fumes when subjected to fire [9]. Besides recently the European Union recently approved the Regulation (EU) 305/2011 [10] related to the Construction Products Regulation (CPR) that will replace the current Directive 89/106/ CEE, already amended by Directive 1993/68/EEC, known as the Construction Products Directive (CPD). A crucial aspect of the new regulation relates to the information regarding hazardous substances [9].Investigations in the field of geopolymers had an exponential increase after the research results of Davidovits [11] who developed and patented binders obtained from the alkali-activation of metakaolin, having named it after the term "geopolymer" in 1978. Its worth remembering that the technology of alkali-activation however predates this terminology by several decades [1214]. For the chemical designation of the geopolymer Davidovits suggested the name "polysialates", in which Sialate is an abbreviation for aluminosilicate oxide. The sialate network is composed of tetrahedral anions $\left[\mathrm{SiO}_{4}\right]^{4-}$ and $\left[\mathrm{AlO}_{4}\right]^{5-}$ sharing the oxygen, which need positive ions such as $\left(\mathrm{Na}^{+}, \mathrm{K}^{+}, \mathrm{Li}^{+}, \mathrm{Ca}^{++}, \mathrm{Na}^{+}, \mathrm{Ba}^{++}, \mathrm{NH}_{4}^{+}, \mathrm{H}_{3} \mathrm{O}^{+}\right)$ to compensate the electric charge of $\mathrm{Al}^{3+}$ in tetrahedral coordination (after dehydroxilation the aluminium changes from coordination 6 (octahedral) to coordination 4 (tetrahedral). Despite all the investigations published on these materials in the last decades some aspects still needed to be further investigated especially concerning durability performance [15-17]. Foam geopolymer constitutes a recent research field with high potential in the development of low toxicity thermal insulators with thermal conductivity value around $0.22 \mathrm{~W} / \mathrm{m} \mathrm{K} \mathrm{[18-20].} \mathrm{This} \mathrm{paper}$
Table 2

Chemical composition of the fly ash.

\begin{tabular}{lllllllll}
\hline $\mathrm{SiO}_{2}$ & $\mathrm{Al}_{2} \mathrm{O}_{3}$ & $\mathrm{Fe}_{2} \mathrm{O}_{3}$ & $\mathrm{CaO}$ & $\mathrm{MgO}$ & $\mathrm{SO}_{3}$ & $\mathrm{~K}_{2} \mathrm{O}$ & $\mathrm{Na}_{2} \mathrm{O}$ & $\mathrm{TiO}_{2}$ \\
\hline 49.12 & 27.3 & 8.19 & 2.36 & 1.42 & 1.3 & 3.34 & 0.99 & 2.32 \\
\hline
\end{tabular}

Table 3

Cost of the materials (euro/kg)

\begin{tabular}{lllllll}
\hline $\begin{array}{l}\text { Calcium } \\
\text { hydroxide }\end{array}$ & $\begin{array}{l}\text { Fly } \\
\text { ash }\end{array}$ & $\begin{array}{l}\text { Sodium } \\
\text { silicate }\end{array}$ & $\begin{array}{l}\text { Sodium } \\
\text { hydroxide }\end{array}$ & Water & $\mathrm{H}_{2} \mathrm{O}_{2}$ & $\mathrm{NaBO}_{3}$ \\
\hline 0.3 & 0.03 & 0.53 & 0.85 & 0.001 & 0.98 & 1.5 \\
\hline
\end{tabular}

discloses results of a study that has investigated the joint effect of several mix parameters on the properties of foam geopolymers fly ash-based.

\section{Experimental work}

\subsection{Materials, mix design, mortar and concrete mixing and concrete coating}

The characteristics of the aggregates (coarse and sand) used are shown in Table 1 and in Fig. 1.The fly ash used in the geopolymeric mortars was supplied by Sines-EDP and according to the NP EN 450-1 it belongs to B class and has an $\mathrm{N}$ class fineness modulus. Its chemical composition is shown in Table 2. Geopolymeric mortars were a mixture of aggregates, fly ash, calcium hydroxide and alkaline silicate solution. The calcium hydroxide was provide by Lusical having a density of $2.211 \mathrm{~g} / \mathrm{cm}^{3}$. A $10 \%$ percentage substitution of fly ash by calcium hydroxide in the mixture was also used. This is because the use of minor calcium hydroxide percentages is pivotal for the strength and durability of geopolymers [16,21,22]. The sand, fly ash and calcium hydroxide were dry mixed before added to the activator. The alkaline activator was prepared prior to use. The activator was a mixture of sodium silicate solution $\left(\mathrm{Na}_{2} \mathrm{O}=13.5 \%, \mathrm{SiO}_{2}=58.7 \%\right.$, and water $\left.=45.2 \%\right)$ and sodium hydroxide. The alkaline activator was prepared prior to use. An activator with sodium silicate solution $\left(\mathrm{Na}_{2} \mathrm{O}=13.5 \%, \mathrm{SiO}_{2}=58.7 \%\right.$, and water $\left.=45.2 \%\right)$ and $12 \mathrm{M}$ sodium hydroxide was used. Two chemical foaming agents (hydrogen peroxide $\left(\mathrm{H}_{2} \mathrm{O}_{2}\right)$ and sodium perborate $\left.\left(\mathrm{NaBO}_{3}\right)\right)$ were used. The hydrogen peroxide is a colourless liquid, slightly more viscous than water and has a density of $1.135 \mathrm{~g} / \mathrm{cm}^{3}$ ate $20{ }^{\circ} \mathrm{C}$. Sodium perborate is a white powder, odourless and water-soluble with the molar mass of $99,815 \mathrm{~g} / \mathrm{mol}$. The cost of the materials is shown in Table 3 . The mix parameters analysed through a laboratory experiment of 54 different mortar mixes were, sodium silicate/sodium hydroxide mass ratio $(2.5,3.5,4.5)$, activator/ binder mass ratio $(0.6,0.8,1.0)$, chemical foaming agent type (hydrogen peroxide $\left(\mathrm{H}_{2} \mathrm{O}_{2}\right)$ and sodium perborate $\left.\left(\mathrm{NaBO}_{3}\right)\right)$ and foaming agent mass ratio content $(1 \%$, $2 \%, 3 \%$ ). The mixing procedure was as follows: the alkaline activator is added to the hydrogen peroxide and both are mixed during $5 \mathrm{~min}$. Then calcium hydroxide and fly ash are added and mixed during 5 more minutes. Finally all the materials are mixed during an extra minute. The fresh mortar were casted and allowed to set at room temperature for $24 \mathrm{~h}$ before being removed from the moulds and kept at room temperature $\left(20^{\circ} \mathrm{C}\right)$ until tested. Bulk density was assess according to the ASTM C 373-78.

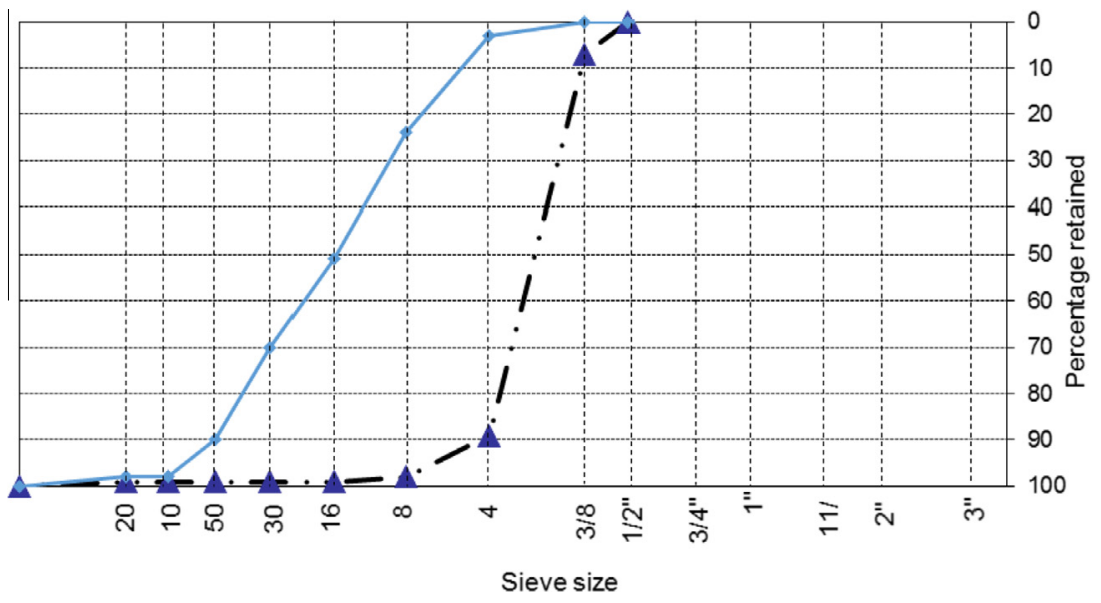

Fig. 1. Aggregate particle size distribution of the sand and of the coarse aggregate. 

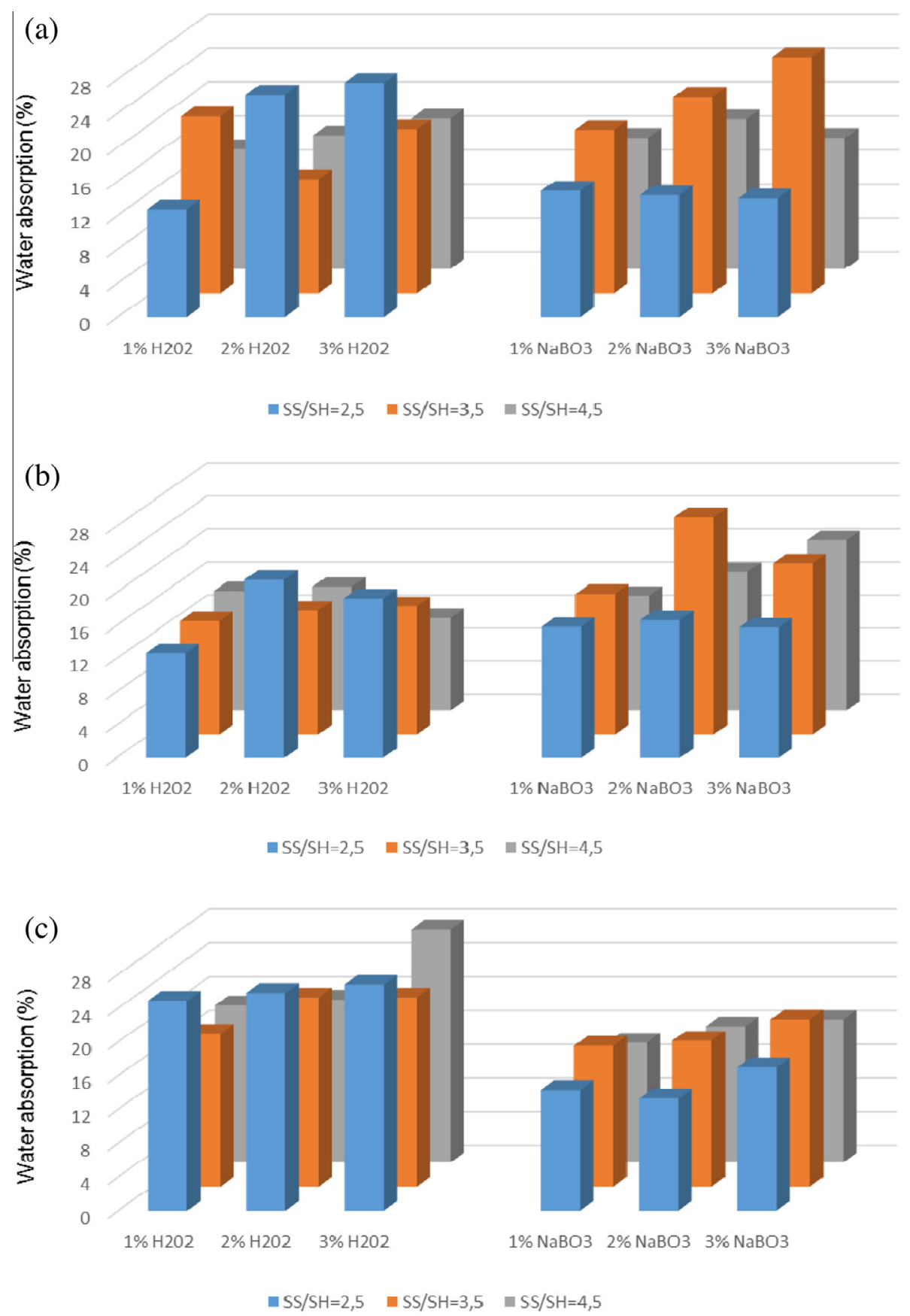

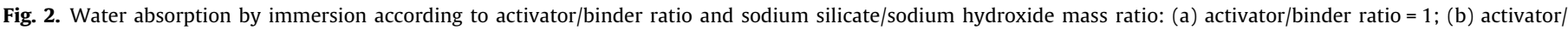
binder ratio $=0.8 ;(c)$ activator $/$ binder ratio $=0.6$.

\section{Experimental procedures}

\subsection{Compressive strength}

Compressive strength were performed on $50 \times 50 \times 50 \mathrm{~mm}^{3}$ concrete specimens according to NP EN 195-1. Compressive strength for each mixture was obtained from an average of 3 cubic specimens. The specimens were tested at after 28 days of curing.

\subsection{Water absorption by immersion}

Tests were performed on $40 \times 40 \times 80 \mathrm{~mm}^{3}$ specimens with 28 days curing. The specimens were immersed in water at room temperature for $24 \mathrm{~h}$. First the weight of the specimens were recorded while suspended by a thin wire and completely submerged in water is recorded as $W_{\mathrm{im}}$ (immersed weight). After that the specimens were removed from water, and placed for $1 \mathrm{~min}$ on a wire mesh allowing water to drain, then visible surface water is removed with a damp cloth and weight is recorded as $W_{\text {sat }}$ (saturated weight). All specimens were placed in a ventilated oven at $105^{\circ} \mathrm{C}$ for not less than $24 \mathrm{~h}$ and allowing that two successive weightings at intervals of $2 \mathrm{~h}$ show an increment of loss not greater than $0.1 \%$ of the last previously determined weight of the specimen. The weight of the dried specimens is recorded as $W_{\text {dry }}$ (oven-dry weight). Absorption coefficient is determined as following equation: 

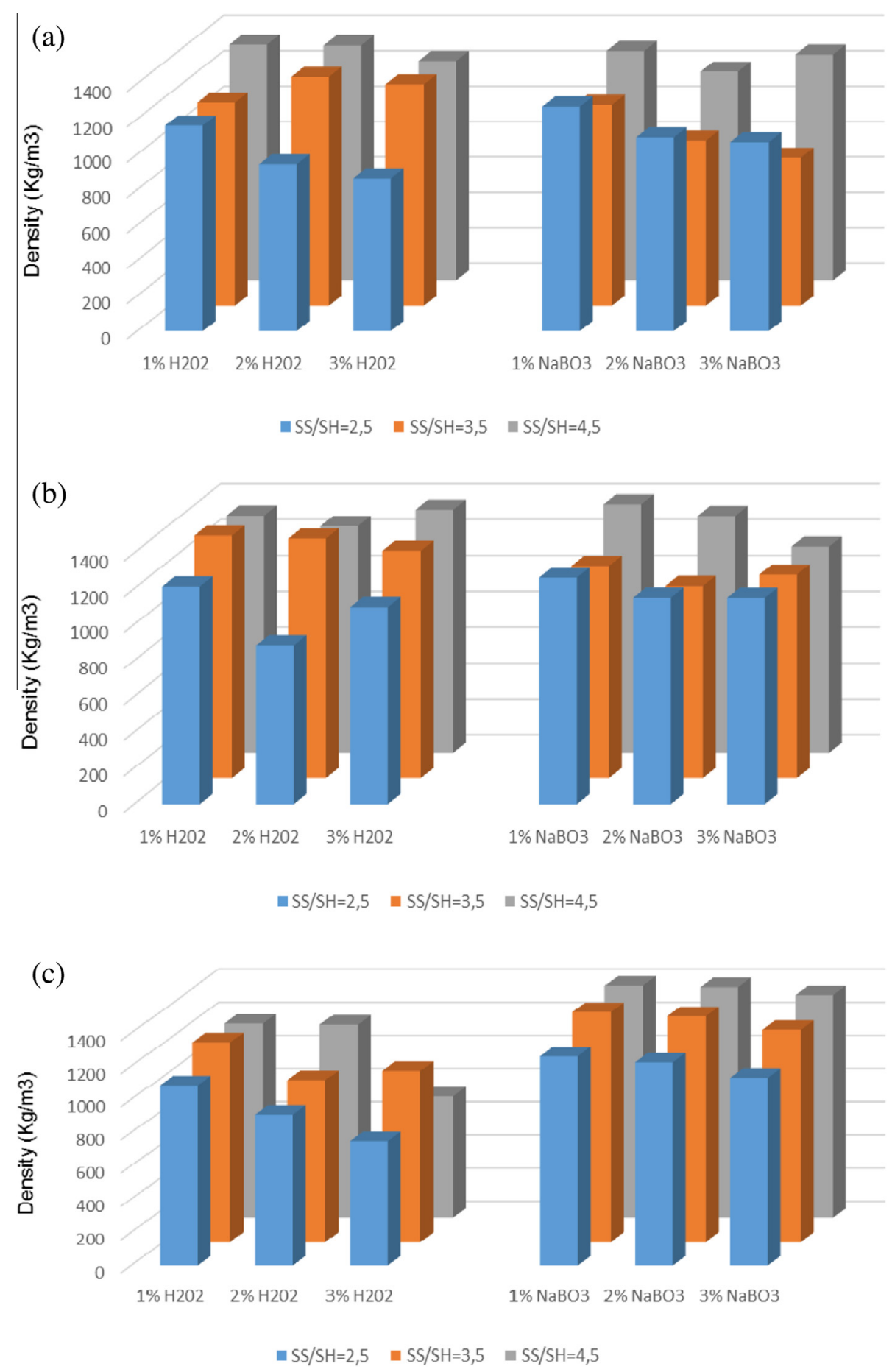

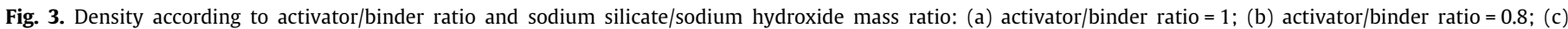
activator/binder ratio $=0.6$.

$A(\%)=\frac{W_{\text {sat }}-W_{\text {dry }}}{W_{\text {sat }}-W_{\text {im }}} \times 100$

\subsection{Thermal conductivity}

Thermal conductivity as assessed using an Alambeta instrument developed at the Technical University of Liberec, Czech Republic. During the measurements, the initial temperature of the samples and the base of the Alambeta were kept at $22-24{ }^{\circ} \mathrm{C}$, and the relative humidity was in the range of $55-65 \%$. To investi- gate the effect of the temperature drop on the thermal properties of the samples, the temperature of the measuring head at first was $10^{\circ} \mathrm{C}$ higher than the environmental temperature. During the second set of measurements, the measuring head was $40^{\circ} \mathrm{C}$ higher than the base plate.

\subsection{Scanning Electron Microscope (SEM) and EDS}

For examination through Scanning Electron Microscopy (SEM), the samples were covered with $40 \mathrm{~nm}$ film of Au-Pd (80-20 

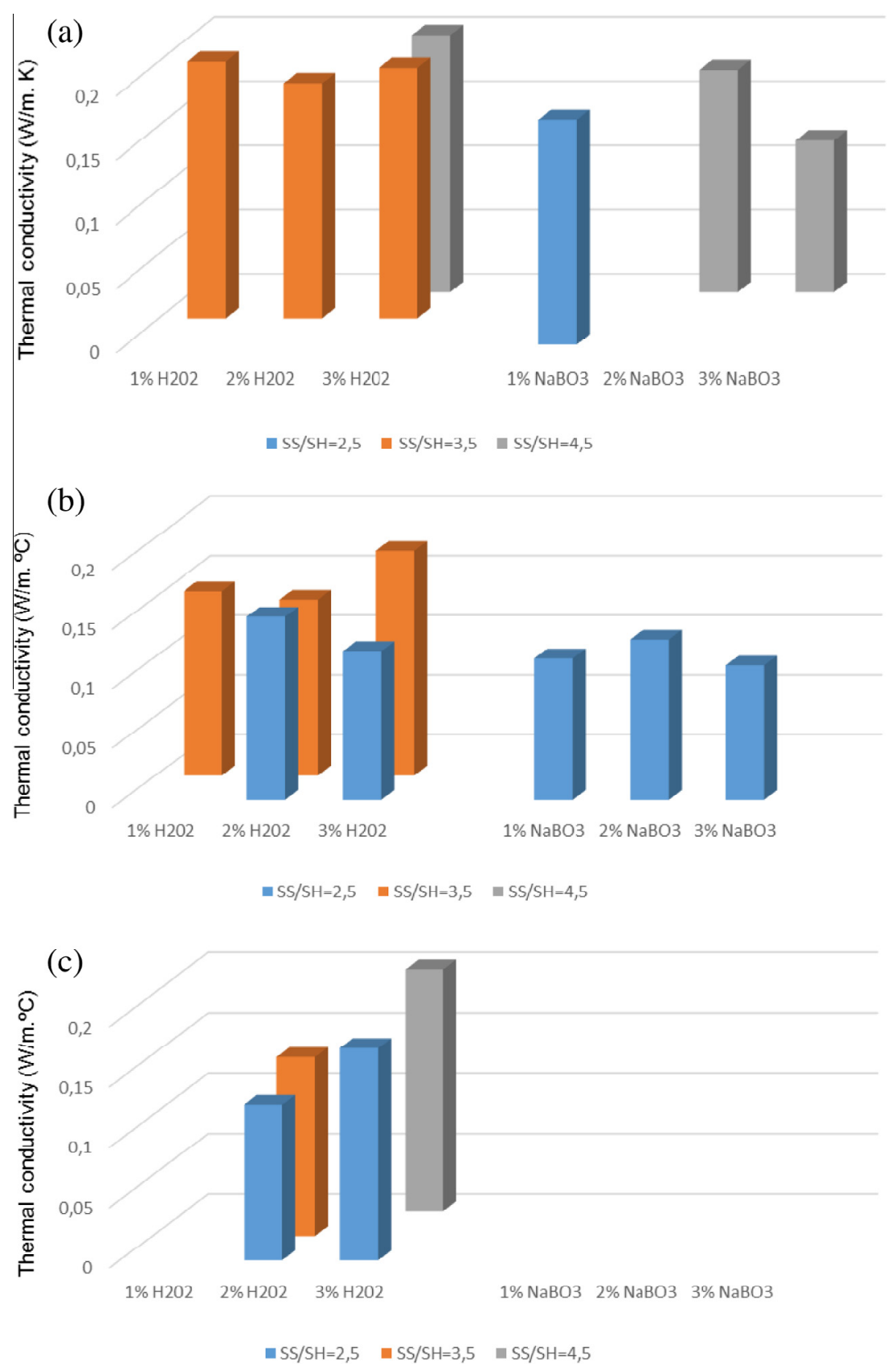

Fig. 4. Thermal conductivity according to activator/binder ratio and sodium silicate/sodium hydroxide mass ratio: (a) activator/binder ratio $=1$; $($ b) activator/binder ratio $=0.8 ;(c)$ activator $/$ binder ratio $=0.6$.

weight\%); in a high resolution sputter coater, 208HR Cressington Company, coupled to a MTM-20 Cressington High Resolution Thickness Controller. Ultra-high resolution Field Emission Gun Scanning Electron Microscopy (FEG-SEM), NOVA 200 Nano SEM and FEI Company were also used. Backscattering Electron images were achieved through an acceleration voltage of $15 \mathrm{kV}$. Chemical analyses of samples were performed with the Energy Dispersive Spectroscopy (EDS) technique, using an EDAX Si (Li) detector with an acceleration voltage of $20 \mathrm{kV}$.

\subsection{Fourier Transform Infrared Spectroscopy (FTIR)}

The FTIR spectra were acquired in the attenuated total reflectance mode (ATR), between 4000 and $550 \mathrm{~cm}^{-1}$, using a Perkin
Elmer FTIR Spectrum BX with an ATR PIKE MIRacle Specimens for FTIR study were prepared by mixing $1 \mathrm{mg}$ of sample in $100 \mathrm{mg}$ of $\mathrm{KBr}$ as .suggested by Zhang et al. [23]. Spectral analysis was performed over the range $4000-400 \mathrm{~cm}^{-1}$ at a resolution of $4 \mathrm{~cm}^{-1}$.

\section{Results and discussion}

\subsection{Water absorption by immersion}

The results of water absorption by immersion are showed in Fig. 2. The lowest water absorption by immersion (11.2\%) was in a mixture with an activator/binder ratio of 0.8 a sodium silicate/ sodium hydroxide of 4.5 and 3\% hydrogen peroxide content. Very 

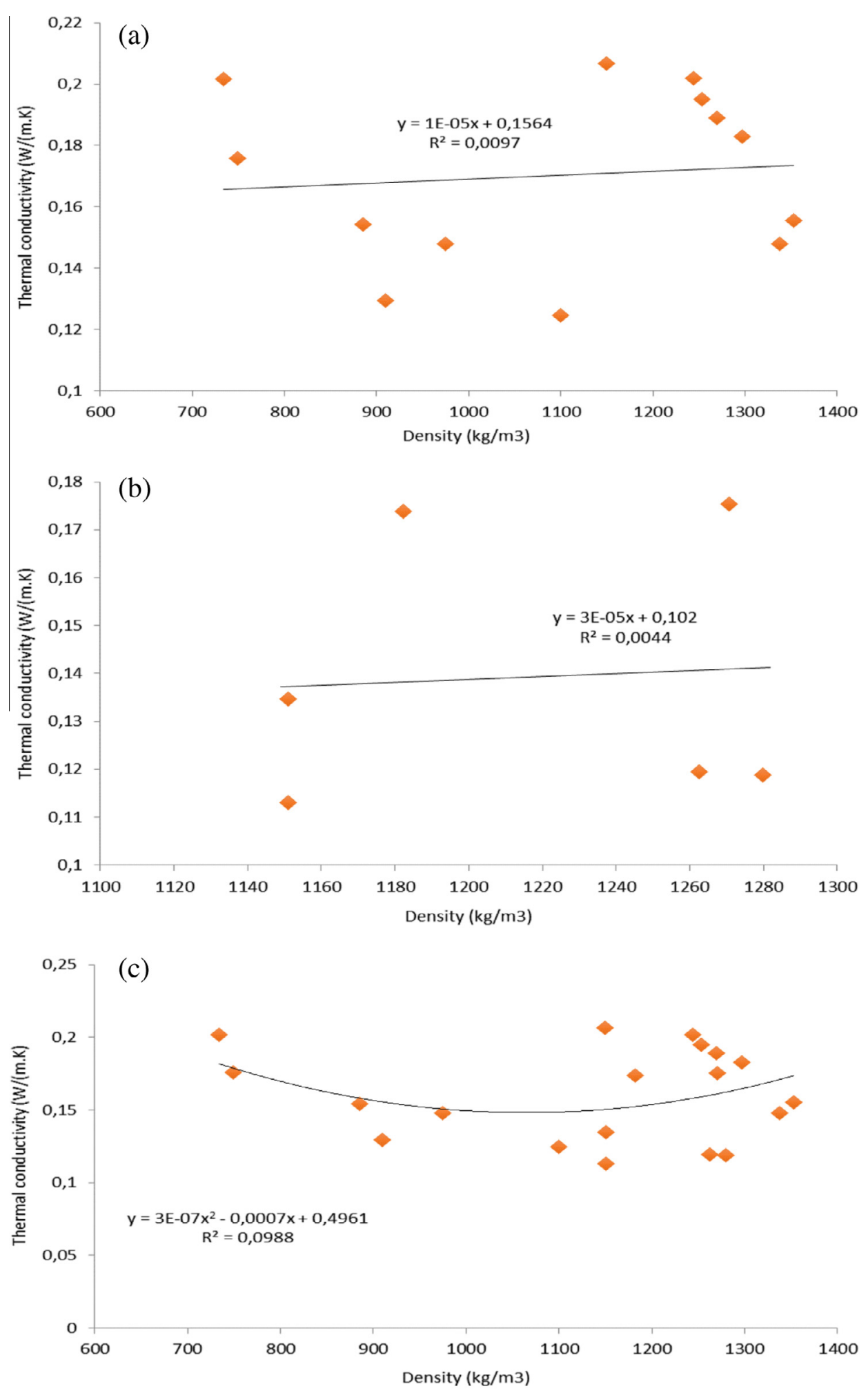

Fig. 5. Thermal conductivity versus density: (a) hydrogen peroxide based geopolymers; (b) sodium perborate based geopolymers; (c) both.

similar and low water absorption values (12.7\%) were found for mixtures with $1 \%$ hydrogen peroxide and a sodium silicate/sodium hydroxide of 2.5. One with an activator/binder ratio of 0.8 and the other with an activator/binder ratio of 1.0. The highest water absorption by immersion (27\%) were found in a mixture with an activator/binder ratio of 1.0 a sodium silicate/sodium hydroxide of 2.5 and $3 \%$ hydrogen peroxide content. A similar high water absorption (27\%) was found in a mixture with an activator/binder ratio of 1.0 a sodium silicate/sodium hydroxide of 3.5 and $3 \%$ sodium perborate content and also in a mixture with an activa- 

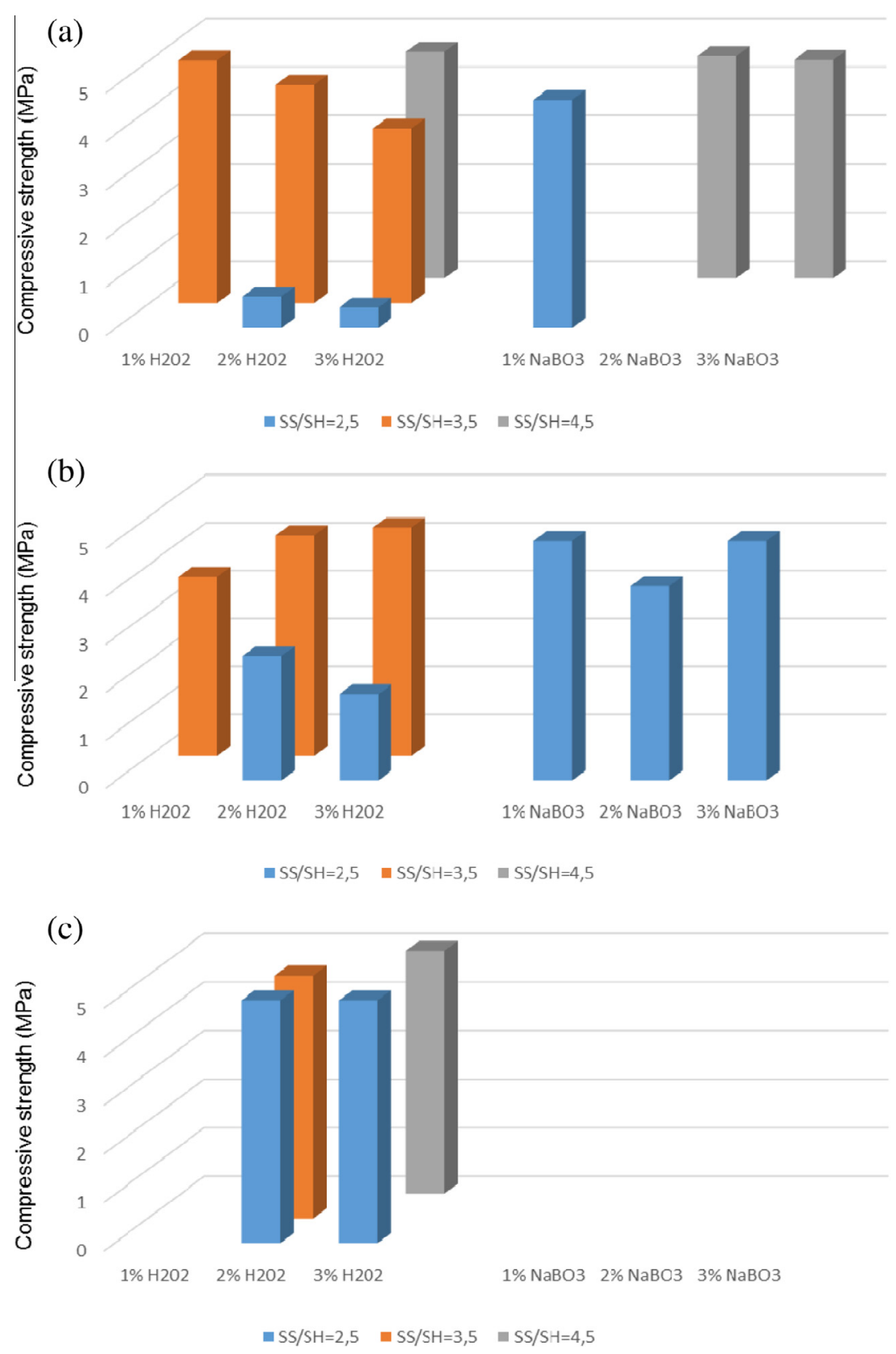

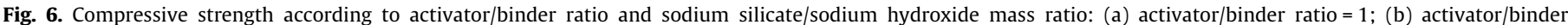
ratio $=0.8 ;(c)$ activator $/$ binder ratio $=0.6$.

tor/binder ratio of 0.6 a sodium silicate/sodium hydroxide of 4.5 and $3 \%$ hydrogen peroxide content. This means that concerning water absorption both foaming agents allow for high porosity mixtures depending on their content and on the ratios activator/binder and sodium silicate/sodium hydroxide.

\subsection{Density}

The results of density are presented in Fig. 3. The lowest density results were found in mixtures with an activator/binder ratio of 0.6 and $3 \%$ hydrogen peroxide content. One with a sodium silicate/ sodium hydroxide of $4.5\left(734 \mathrm{~kg} / \mathrm{m}^{3}\right)$ and other with a sodium silicate/sodium hydroxide of $2.5\left(749 \mathrm{~kg} / \mathrm{m}^{3}\right)$. As a general trend the increase of foaming agent leads to a lower density. However, the opposite can also take place. That's the case of hydrogen peroxide based mixtures with an activator/binder ratio of 1.0 a sodium silicate/sodium hydroxide of 3.5.

\subsection{Thermal conductivity}

Fig. 4 shows the results of the thermal conductivity. The missing values are related to high density mixtures. The lowest thermal conductivity performance was achieved $(0.113 \mathrm{~W} / \mathrm{m} \mathrm{K})$ in a mixture with an activator/binder ratio of 0.8 a sodium silicate/sodium hydroxide of 2.5 and $3 \%$ sodium perborate content. A similar thermal conductivity was obtain in a mixture with the same activator/ binder ratio, the same sodium silicate/sodium hydroxide ratio and $1 \%$ sodium perborate content $(0.1195 \mathrm{~W} / \mathrm{m} \mathrm{K})$. A mixture with the same sodium silicate/sodium hydroxide of 2.5 with an activator/ binder ratio of 0.6 and $2 \%$ hydrogen peroxide content also lead to a low thermal conductivity $(0.1293 \mathrm{~W} / \mathrm{m} \mathrm{K})$. Another sodium perborate based mixtures with an activator/binder ratio of 1.0 and a sodium silicate/sodium hydroxide of 4.5 also led to a low thermal conductivity $(0.1187 \mathrm{~W} / \mathrm{m} \mathrm{K})$. These results outperform the thermal conductivity of commercial autoclaved aerated concrete 

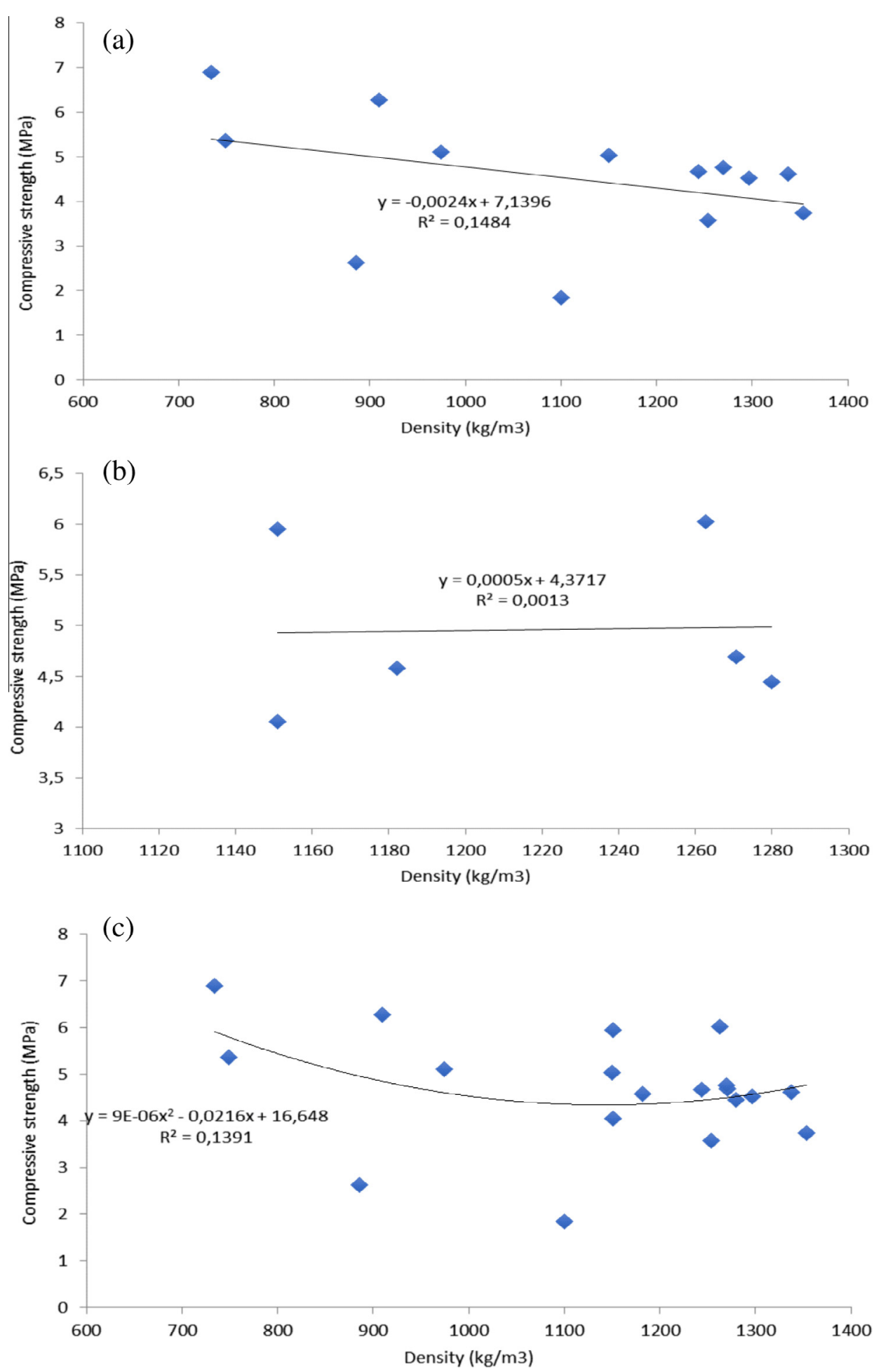

Fig. 7. Compressive strength versus density: (a) Hydrogen peroxide based geopolymers; (b) sodium perborate based geopolymers; (c) both.

masonry blocks (Ytong) of around $(0.17 \mathrm{~W} / \mathrm{m} \mathrm{K})$. No valid statistic correlation was found between thermal conductivity and density (Fig. 5). Different sodium silicate/sodium hydroxide ratios and different activator/binder ratios could explain this.

\subsection{Compressive strength}

Fig. 6 shows the results of the compressive strength. Low compressive strength results (below $3 \mathrm{MPa}$ ) were found in hydrogen peroxide mixtures (2\% and $3 \%$ ) with an activator/binder ratio of 0.8 and a sodium silicate/sodium hydroxide of 2.5 . It's important to mention that the mixtures with a low thermal conductivity mentioned in Section 4.3 showed a compressive strength in the range of 4.5-6.0 MPa wile commercial autoclaved aerated concrete masonry blocks have an average compressive strength above 4.5 MPa. No valid statistic correlation was found between compressive strength and density due to the variation of the results and the limited number of test samples (Fig. 7). 

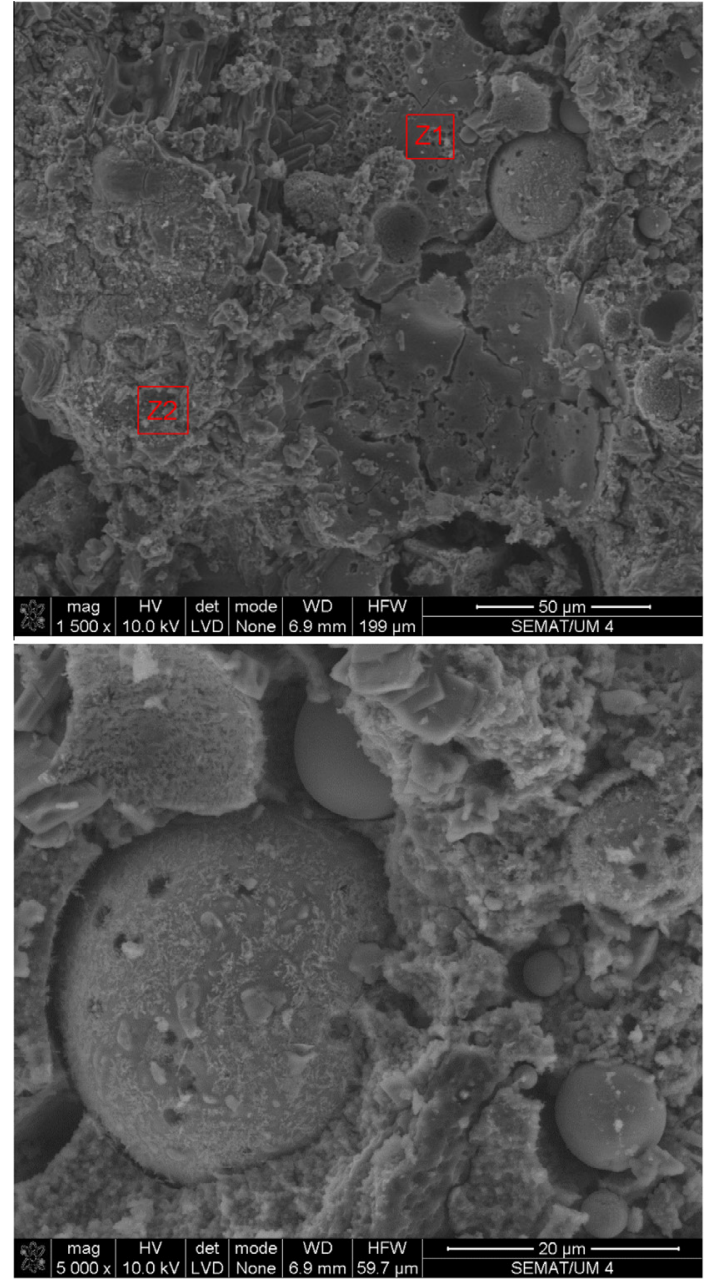

Fig. 8. SEM mix FG A.

\subsection{Scanning Electron Microscopy analysis}

Figs. 8-10 show the microstructure of three foam geopolymer mixtures. Their composition is shown in Table 4 while the EDS atomic ratios of two points for each mixture are presented in Table 4. The microstructure of the three samples shows different level of unreacted fly ash particles. This is consistent with their compressive strength respectively $4.6 \mathrm{MPa}, 5.36 \mathrm{MPa}$ and 6.89 MPa. All EDS atomic ratios show a low $\mathrm{C} / \mathrm{S}$ ratio. Typical C/S ratios in CSH of traditional OPC systems are situated from 1.5 to 2.0 [24]. Meaning there has been some sodium replacing $\mathrm{Ca}^{2+}$ in $\mathrm{CSH}$. Some authors have already demonstrated that sodium incorporation in the CSH phase increases as $\mathrm{C} / \mathrm{S}$ ratio decreases [25]. All EDS analysis show hydration products with a $\mathrm{SiO}_{2} / \mathrm{Al}_{2} \mathrm{O}_{3}$ higher than the original $\mathrm{SiO}_{2} / \mathrm{Al}_{2} \mathrm{O}_{3}$ fly ash ratio which is explained by the $\mathrm{Si}$ species added trough the used of the sodium silicate. FG $\mathrm{B}$ and $\mathrm{FG} \mathrm{C}$ show similar $\mathrm{SiO}_{2} / \mathrm{Al}_{2} \mathrm{O}_{3}$ atomic ratios although they used very different sodium silicate contents in their composition. This could mean that the extra $\mathrm{Si}$ species have not contributed to the formation of the hardened alkaline aluminosilicate structure and that an optimum sodium silicate content exists.

\subsection{Fourier Transform Infrared Spectroscopy (FTIR) analysis}

The IR spectra of the three hardened foam geopolymer mixtures (Table 5) are presented in Fig. 11. Strong vibration typical of alumi-
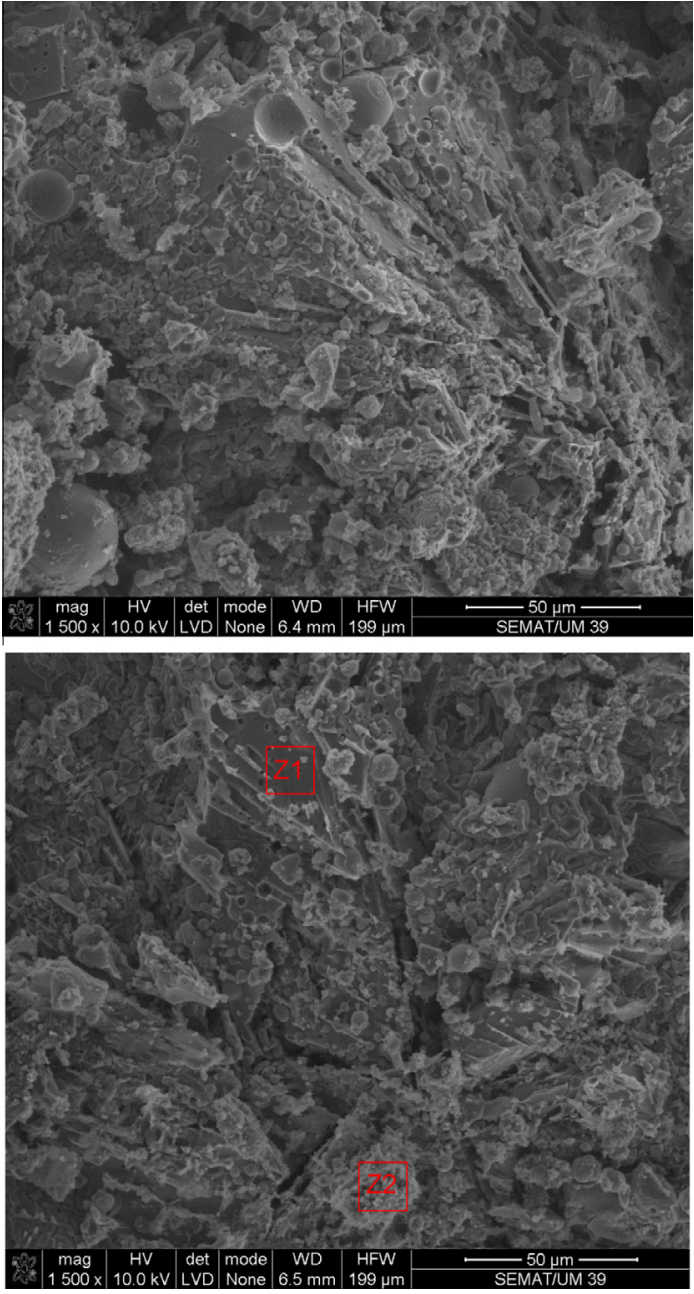

Fig. 9. SEM mix FG B.

nosilicates can be seeing. The peak centered around 959 and $965 \mathrm{~cm}^{-1}$ is characteristic of a geopolymerization reaction corresponding to the $\mathrm{Si}-\mathrm{O}-\mathrm{Al}$ and $\mathrm{Si}-\mathrm{O}-\mathrm{Si}$ vibration bands. The band at about $864 \mathrm{~cm}^{-1}$ (Fig. 11c) is assigned to $\mathrm{Si}-\mathrm{OH}$ bending vibration. This mixture had a sodium silicate/sodium hydroxide of 4.5 . The absorption band around 1394, 1396 and $1405 \mathrm{~cm}^{-1}$ is attributed to stretching vibrations of $\mathrm{CO}_{3}^{2-}$ ions confirming the existence of carbonate species [26]. Atmospheric $\mathrm{CO}_{2}$ enter in geopolymer to reacting with unhydrated sodium to form sodium carbonate.

\subsection{Cost analysis}

Since the sodium perborate has a cost $50 \%$ higher than the hydrogen peroxide it is important to assess how can this influence the overall cost performance of the different mixtures. Fig. 12 shows the cost of the foam geopolymer mixtures according to the activator/binder ratio and sodium silicate/sodium hydroxide mass ratio. The lower the activator/binder ratio, the lower the cost. This is because the cost percentage of foaming agents is just around $10 \%$ the total cost (Table 3 ). Alkaline activators being responsible for $80 \%$ of the cost. Current investigations aiming to replace sodium silicate by low cost waste glass [27] will increase the cost efficiency of foam geopolymer mixtures. Fig. 13 shows the cost to thermal resistance ratio. Fig. 14 shows the cost to thermal resistance ratio for several activator/binder ratios. The mixture with the higher performance uses sodium perborate with a activa- 
Table 4

EDS atomic ratios.

\begin{tabular}{|c|c|c|c|c|c|c|c|}
\hline & \multirow[t]{2}{*}{ Fly ash } & \multicolumn{2}{|l|}{ FG A } & \multicolumn{2}{|l|}{ FG B } & \multicolumn{2}{|l|}{ FG C } \\
\hline & & $\mathrm{Z1}$ & $\mathrm{Z2}$ & $\mathrm{Z1}$ & $\mathrm{Z} 2$ & $\mathrm{Z1}$ & $\mathrm{Z2}$ \\
\hline $\mathrm{SiO}_{2} / \mathrm{Al}_{2} \mathrm{O}_{3}$ & 3.05 & 19.57 & 10.33 & 9.86 & 9.78 & 9.92 & 8.24 \\
\hline $\mathrm{Al}_{2} \mathrm{O}_{3} / \mathrm{Na}_{2} \mathrm{O}$ & 16.75 & 0.13 & 0.14 & 0.30 & 0.15 & 0.45 & 0.63 \\
\hline $\mathrm{CaO} / \mathrm{SiO}_{2}$ & 0.05 & 0.47 & 0.1 & 0.27 & 0.14 & 0.28 & 0.28 \\
\hline $\mathrm{Na}_{2} \mathrm{O} / \mathrm{CaO}$ & 0.38 & 0.78 & 6.49 & 1.22 & 4.35 & 0.75 & 0.67 \\
\hline $\mathrm{MgO} / \mathrm{Al}_{2} \mathrm{O}_{3}$ & 0.13 & 0.57 & 0.29 & 0.27 & 0.44 & 0.31 & 0.38 \\
\hline $\mathrm{Fe}_{2} \mathrm{O}_{3} / \mathrm{Al}_{2} \mathrm{O}_{3}$ & 0.19 & 0.30 & 0.09 & 0.14 & 0.08 & 0.24 & 0.16 \\
\hline
\end{tabular}

Table 5

Content of geopolymer samples used for FTIR.

\begin{tabular}{lllll}
\hline Sample & $\begin{array}{l}\text { Activator/ } \\
\text { binder }\end{array}$ & $\begin{array}{l}\text { Sodium silicate/sodium } \\
\text { hydroxide mass ratio (SS/ } \\
\text { SH) }\end{array}$ & $\begin{array}{l}\text { Foam } \\
\text { agent } \\
\text { type }\end{array}$ & $\begin{array}{l}\text { Foam agent } \\
\text { content (\%) }\end{array}$ \\
\hline FG A & 1 & 2.5 & $\mathrm{NaBO}_{3}$ & 1 \\
FG B & 0.6 & 4.5 & $\mathrm{H}_{2} \mathrm{O}_{2}$ & 3 \\
FG C & & 4.5 & & \\
\hline
\end{tabular}
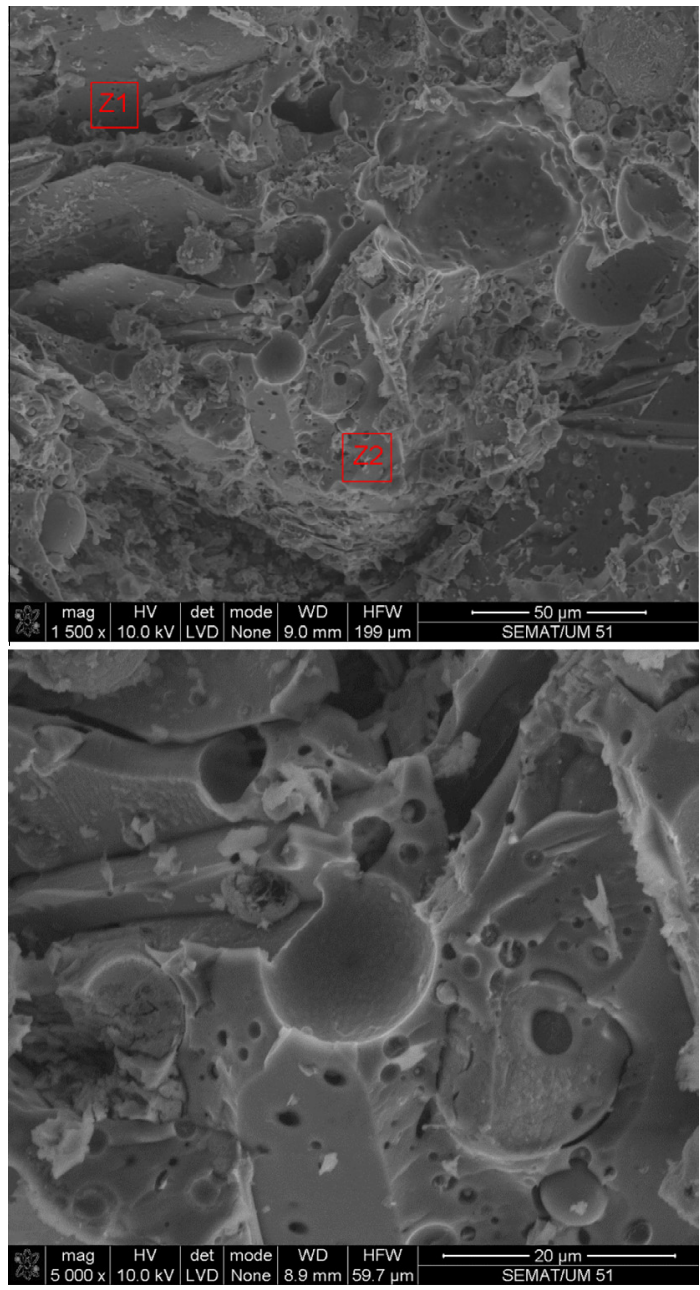

Fig. 10. SEM mix FG C.

tor/binder ratio of 1.0 and sodium silicate/sodium hydroxide mass ratio of 4.5 . Hydrogen peroxide based mixtures (3\% and $2 \%$ content) with and activator/binder ratio of 0.8 and a sodium silicate/ sodium hydroxide mass ratio of 2.5 and 3.5 also present a low cost to thermal resistance ratio. (a)

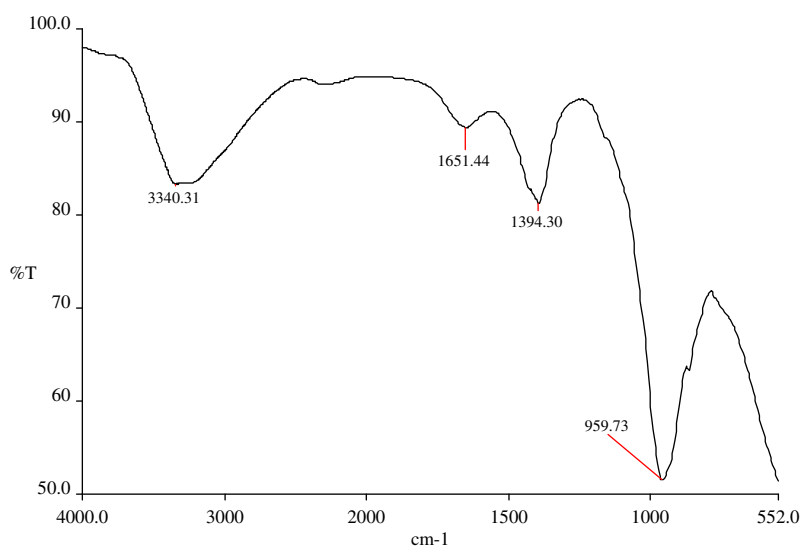

(b)

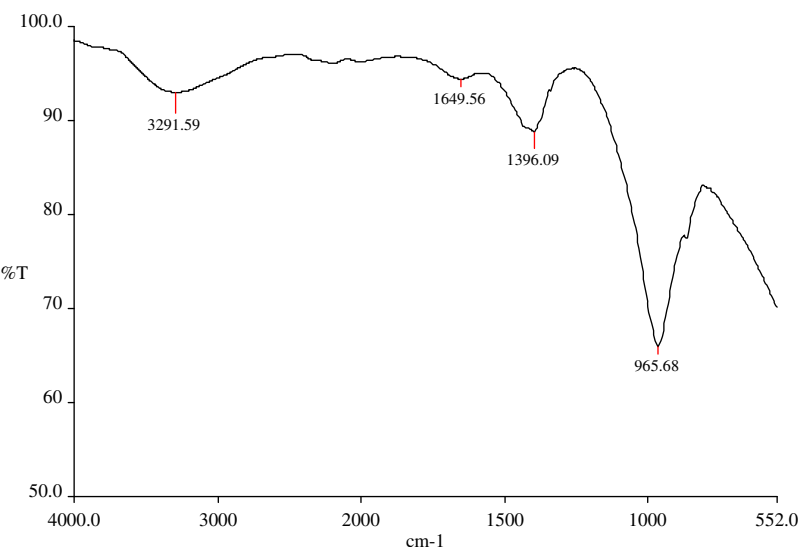

(c)

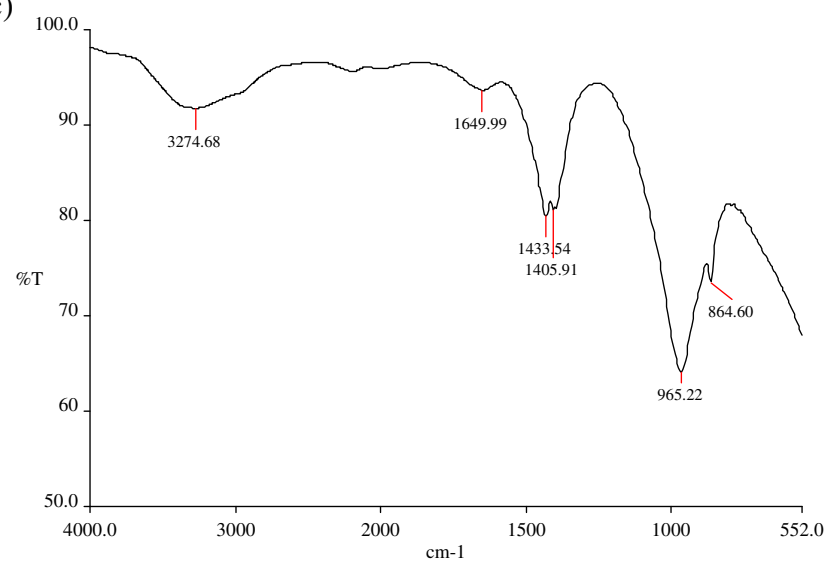

Fig. 11. IR bands of foam geopolymers: (a) FG A; (b) FG B; (c) FG C.

\section{Conclusions}

The increasing demand for worldwide energy, is a major cause for the unsustainable development of our Planet. The use of thermal insulation materials constitutes the most effective way of reducing heat losses in buildings thus reducing heat energy needs. However, current insulation materials are associated with negative impacts in terms of toxicity. Not only during the production phase but also releasing toxic fumes when subjected to fire. This paper discloses results of a study that has investigated the joint effect of several mix parameters on the properties of foam geopolymers fly ash-based. The results show that the sodium perborate over performs hydrogen peroxide leading to a lower overall thermal conductibility of foam geopolymers. The use of an activator/binder ratio of 0.8 and a sodium silicate/sodium hydroxide of 2.5 led to 

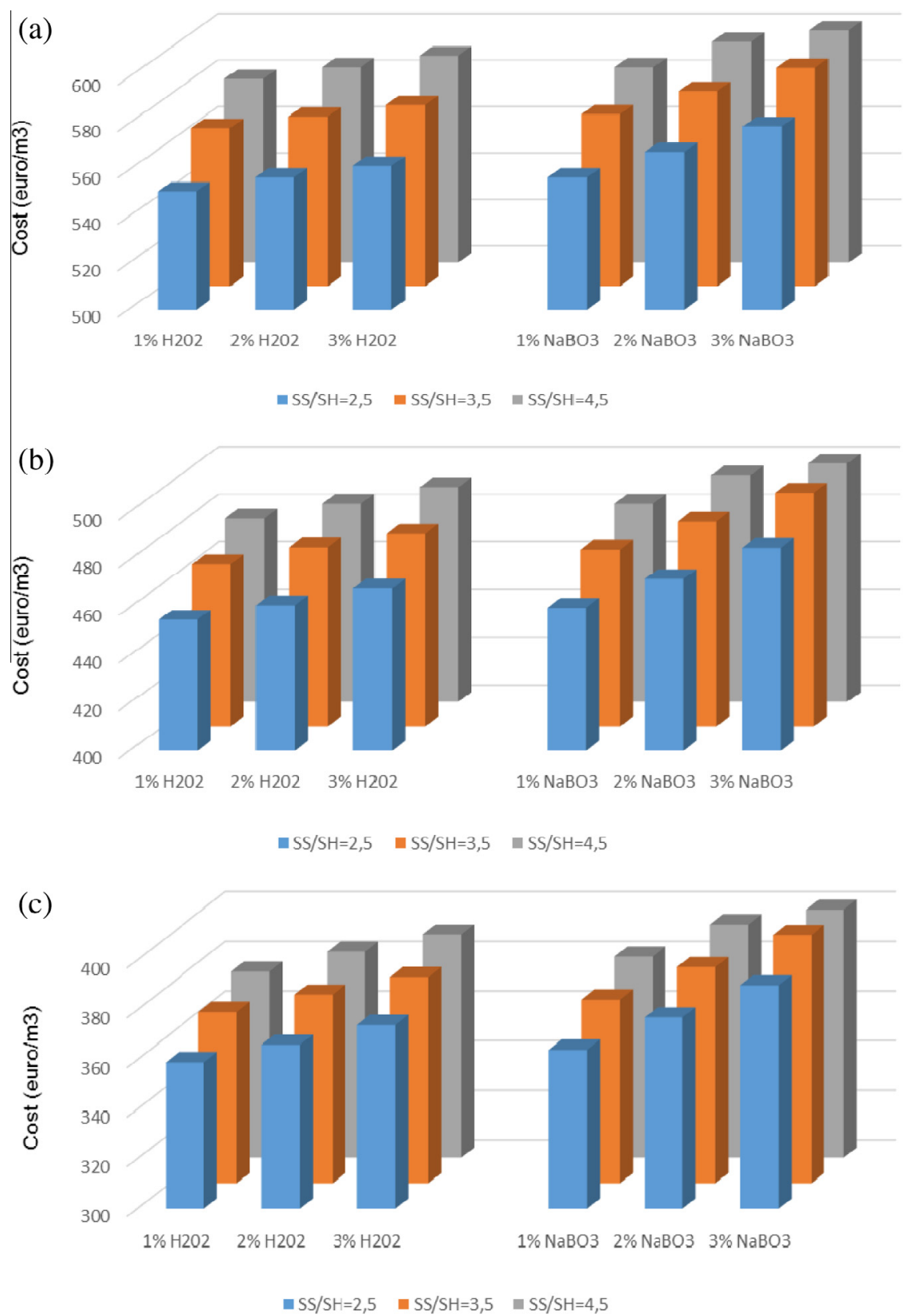

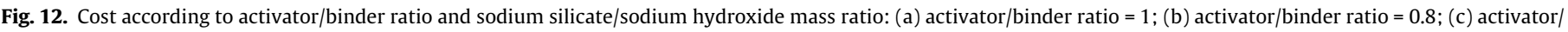
binder ratio $=0.6$.

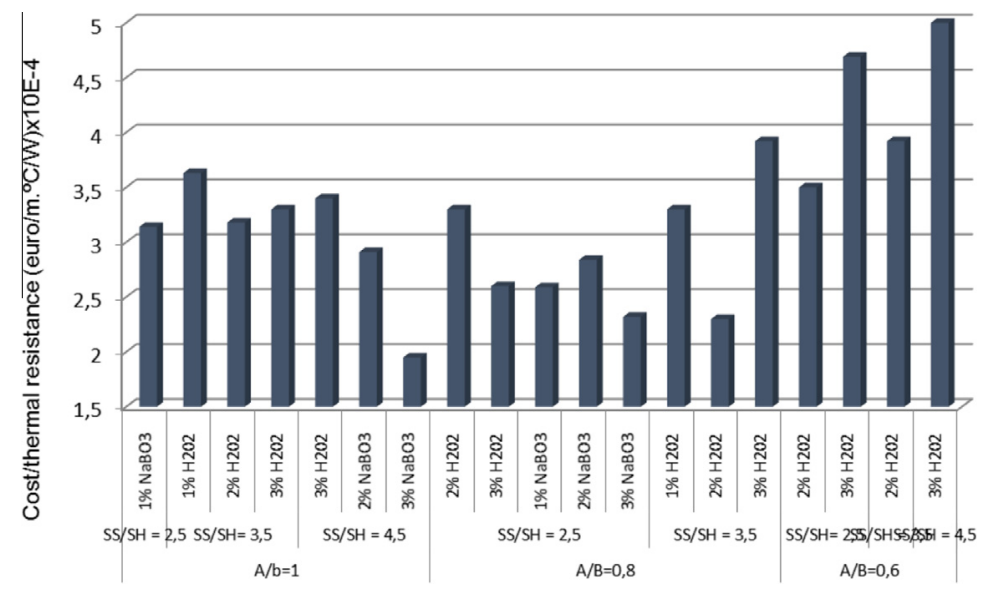

Fig. 13. Cost to thermal resistance ratio. 

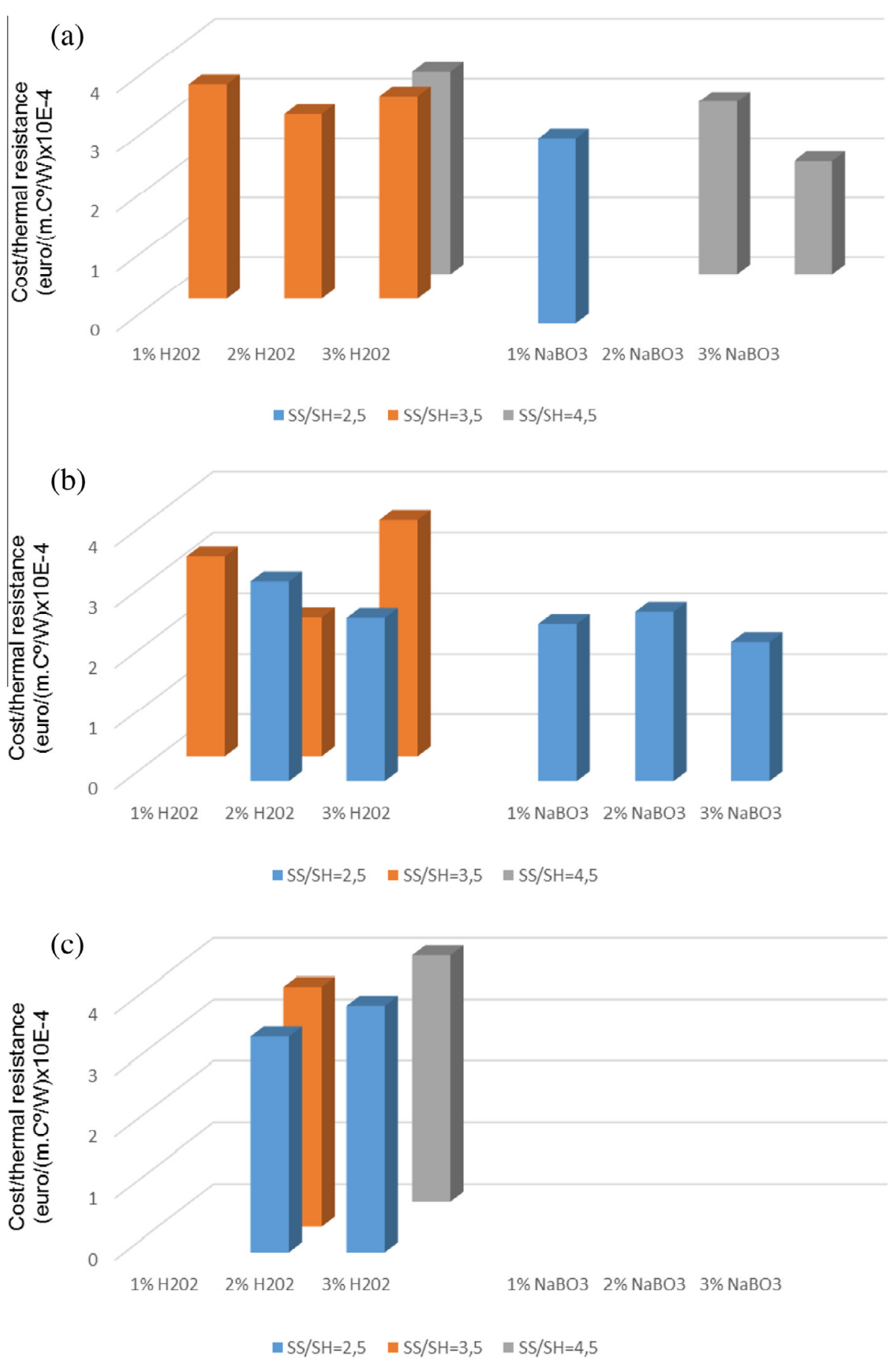

Fig. 14. Cost to thermal resistance ratio: (a) activator/binder ratio $=1$; $(\mathrm{b})$ activator $/$ binder ratio $=0.8$; $(c)$ activator $/$ binder ratio $=0.6$.

the lowest thermal conductivity. Mixtures with a low thermal conductivity of around $0.1 \mathrm{~W} /(\mathrm{m} \mathrm{K})$ and a compressive strength of around $6 \mathrm{MPa}$ were achieved. The cost analysis show the foaming agents are responsible for a small percentage of foam geopolymers total cost (less than $10 \%$ ) being that the alkaline activators are responsible for more than $80 \%$.

\section{References}

[1] Pacheco-Torgal F, Jalali S. Eco-efficient construction and building materials. London, UK: Springer Verlag; 2011.

[2] UN. Energy for a sustainable future. New York: The Secretary-General's Advisory Group on energy and climate change; 2010.
[3] WHO (2014) Urban population growth. Global health observatory. <http:// www.who.int/gho/urban_health/situation_trends/urban_population_growth text/en/>.

[4] OCDE (2003) Environmental sustainable building-challenges and policies, Paris.

[5] COM (2011) 885/2. Energy Roadmap 2050.

[6] COM 815 (2011) Progress report on the Europe 2020 strategy.

[7] Pacheco-Torgal F, Cabeza L, Mistretta M, Kaklauskas A, Granqvist G. Nearly zero energy building refurbishment. A multidisciplinary approach. London, UK: Springer Verlag; 2013.

[8] Pacheco-Torgal F. Eco-efficient construction and building materials research under the EU Framework Programme Horizon 2020. Constr Build Mater 2014;51:151-62.

[9] Pacheco-Torgal F, Fucic A, Jalali S. Toxicity of building materials. Cambridge, UK: Woodhead Publishing Limited Abington Hall; 2012.

[10] Regulation (EU) 305/2011 - Construction Products Regulation. 
[11] Davidovits, J. (1979) Synthesis of new high temperature geo-polymers for reinforced plastics/composites. SPE PACTEC 79 Society of Plastic Engineers, Brookfield Center, pp. 151-154.

[12] Pacheco-Torgal F., Labrincha J.A., Leonelli C., Palomo A., Chindaprasirt P. (2014) Handbook of Alkali-Activated Cements, Mortars and Concretes ed. 1. Abington Hall, Cambridge, UK: WoodHead Publishing Limited - Elsevier Science and Technology.

[13] Provis JL. Geopolymers and other alkali activated materials: why, how, and what? Mater Struct 2014;47:11-25.

[14] Provis JL, Van Deventer JSJ, editors. Geopolymers: structure, processing, properties and industrial applications. Cambridge, UK: Woodhead Publishing; 2009.

[15] Pacheco-Torgal F, Abdollahnejad Z, Camões A, Jamshidi M, Ding Y. Durability of alkali-activated binders. A clear advantage over Portland cement or an unproven issue ? Constr Build Mater 2012;30:400-5.

[16] Van Deventer JSJ, Provis J, Duxson P. Technical and commercial progress in the adoption of geopolymer cement. Miner Eng 2012;29:89-104.

[17] J.L. Provis, Durability of geopolymers as 21 st century concretes. ERC Starting grant for the period 2013-2018.

[18] Prud'homme E, Michaud P, Joussein E, Peyratout C, Smith A, Arrii-Clacens S, et al. Silica fume as porogent agent in geo-materials at low temperature. J Eur Ceram Soc 2010;30:1641-8.

[19] Shi D, Shi L, Zhang J, Cheng J. Preparation and properties of a novel nonflammable thermal insulation material. Adv Mater Res 2012;450451:1504-12.
[20] Zhang Z, Provis JL, Reid A, Wang H. Geopolymer foam concrete: an emerging material for sustainable construction (2014). Constr Build Mater 2014;56:113-27.

[21] Yip C, Lukey G, Deventer SJS. The coexistence of geopolymeric gel and calcium silicate hydrate gel at the early stage of alkaline activation. Cem Concr Res 2005;35:1688-97.

[22] Pacheco-Torgal F, Gomes JP, Jalali S. Investigations on mix design of tungsten mine waste geopolymeric binders. Constr Build Mater 2008;22:1939-49.

[23] Zhang M, Wruck B, Graeme - Barber A, Salje E, Carpenter M. Phononspectroscopy on alkali-feldspar: phase transitions and solid solutions. Am Mineral 1996;81(1996):92-104.

[24] Diamond S. C/S mole ratio of $\mathrm{CSH}$ gel in a mature $\mathrm{C}_{3} \mathrm{~S}$ paste as determined by EDXA. Cem Concr Res 1976;6:413-6.

[25] Macphee DE. Solubility and aging of calcium silicate hydrates in alkaline solutions at $25^{\circ} \mathrm{C}$. J Am Ceram Soc 1989;72:646-54.

[26] Fernandez-Jimenez A, Palomo A. Mid-infrared spectroscopic studies of alkali activated fly ash structure. Microporous Mesoporous 2005;86:207-14.

[27] Puertas F, Torres-Carrasco M, Alonso M. Reuse of urban and industrial waste glass as novel activator for alkali-activated slag cement pastes: A case study. In: Pacheco-Torgal F, Labrincha JA, Leonelli C, Palomo A, Chindaprasirt P, editors. Handbook of Alkali-Activated Cements, Mortars and Concretes. Abington Hall, Cambridge, UK: WoodHead Publishing Limited Elsevier Science; 2014. 